\title{
A UNILAB NA PERSPECTIVA DA COOPERAÇÃO SUL-SUL: UMA ANÁLISE CRÍTICA DECOLONIAL AFRICANA
}

\section{UNILAB in the perspective of South-South cooperation: a critical african decolonial analysis}

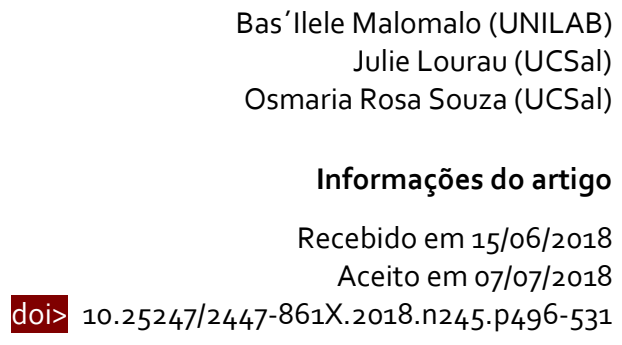

\begin{abstract}
Resumo
Este trabalho tem por objetivo, pautando-se nos trabalhos anteriores de seus autores, discutir criticamente a cooperação internacional entre Brasil e África, tendo a Universidade da Integração Internacional da Lusofonia Afro-brasileira (UNILAB) como objeto de estudo. O período considerado para a análise é de 2003 até 2018. O ano 2003 até 2010 corresponde aos dois mandatos do governo Lula, durante os quais germinou-se o projeto da UNILAB mediante a composição de uma comissão de implementação, que elaborou suas Diretrizes, em 2008, e de promulgação da lei da sua fundação. O segundo período é da era Dilma Rousseff entre seu primeiro mandato (2010-2014) e o seu segundo mandato que inicia em 2014 e é interrompido pelo golpe parlamentar em 2016. Busca-se interpretar a história da cooperação entre Brasil e África, partindo das dinâmicas internas da UNILAB na sua relação com as dinâmicas regionais, nacionais e internacionais. Por isso, dá-se o foco nas sucessivas gestões superiores, as reitorias pro tempore que governaram a universidade. $O$ último período que o texto leva em consideração é aquele que coincide com o golpe parlamentar contra a presidenta Dilma Rousseff e a nomeação de um reitor pro tempore oriundo desse processo político conturbador. Focase em alguns aspectos considerados essenciais para a construção de uma narrativa emancipatória que leva em conta o pensamento do Sul global, especialmente decolonial africano e afro-diaspórico.
\end{abstract}

Palabras-chave: Cooperação Sul-sul. UNILAB. Brasil-África. Epistemologia decolonial.

\section{Abstract}

Based on previous work by its authors, this paper aims to critically discuss international cooperation between Brazil and Africa, with the University of the international integration of Afro-Brazilian lusophony (UNILAB) as the object of study. The period considered for the analysis is from 2003 to 2018 . The year 2003 until 2010 marks the period of the two terms of the Lula government, during which the Unilab project was formed through the composition of an implementation committee that drafted its Guidelines, in 2008, and promulgating the law of its foundation. The second period that supports the analysis of this text is of the Rousseff era. His first term (2010-2014) and his second term, which begins in 2014, is interrupted by the parliamentary coup in 2016. The aim is to interpret the history of cooperation between Brazil and Africa, starting from the internal dynamics of UNILAB in its relation with the regional, national and international dynamics. Hence, the focus is on the successive higher administrations, the pro-tempore rectors that governed the university. The last period that the text takes into account is the one that coincides with the parliamentary coup against President Dilma Rousseff and the appointment of a protempore dean from this troublesome political process. It focuses on some aspects considered essential for the construction of an emancipatory narrative that takes into account the thinking of the global South, especially Decolonial African and Afrodiasporic.

Keywords: South-South cooperation. UNILAB. Brazil-Africa. Decolonial Epistemology. 


\section{Introdução}

A Universidade da Integração Internacional da Lusofonia Afro-brasileira (UNILAB) é, hoje, uma comunidade acadêmica internacional implementada em duas regiões interioranas nordestinas, maciço do Baturité, no Ceará, nos municípios de Acarape e Redenção, e no Recôncavo histórico baiano, no município de São Francisco do Conde. Comporta 6.529 estudantes de cursos presenciais e a distância na sua modalidade de graduação e pósgraduação. Ou seja, 2.616 estudantes brasileiros/as de cursos a distância, e 3.976 estudantes brasileiros/as e internacionais (estrangeiros/as) matriculados em cursos presenciais de graduação. Deste último número, 2.942 são brasileiros e 1.034 são internacionais, oriundos dos países da cooperação: Angola (180), Cabo Verde (83), Moçambique (37), Guiné Bissau (628), São Tomé e Príncipe (78) e Timor Leste (28). Nos cursos a distância, encontram-se na graduação 752 estudantes brasileiros/as e na pós-graduação latu sensu 1.694 estudantes brasileiros/as. Nos três cursos de pós-graduação stricto sensu, dentro do número absoluto de 104 estudantes matriculados/as, 99 são brasileiros/as e são 5 guineenses ${ }^{1}$.

A universidade comporta 622 servidores/as, sendo 345 técnico-administrativos em educação, brasileiros, e nenhum deles advém dos países da cooperação. Há 277 docentes, sendo 242 brasileiros/as e 21 professores/as estrangeiros/as, dos quais 19 são africanos/as dos PALOP ${ }^{2}$.

Este trabalho tem por objetivo, pautando-se nos trabalhos anteriores de seus autores, discutir criticamente a cooperação internacional entre Brasil e África, tendo a UNILAB como objeto de estudo. Foca-se em alguns aspectos considerados essenciais para a construção de uma narrativa emancipatória que leva em conta o pensamento do Sul global, especialmente decolonial africano e afro-diaspórico.

O período considerado para a análise é de 2003 até 2018. De 2003 até 2010 marca o período dos dois mandatos do governo Lula, durante os quais germinou-se o projeto da

1 Números calculados pelo/as autor/as a partir das informações disponibilizadas pelo Serviço de comunicação da UNILAB (Disponível em:< http://www.unilab.edu.br/unilab-em-numeros/>. Acessado em 8 jun. 2018) e Diretoria de Registros e Controle Acadêmico - DRCA (Dados de abril/2015. Disponível em:< http://www.unilab.edu.br/dadosquantitativos/>. Acessado em 8 jun. 2018).

2 Informações disponibilizadas pelo Serviço de comunicação da UNILAB (Disponível em:< http://www.unilab.edu.br/unilab-em-numeros/>. Acessado em 8 jun. 2018. 
UNILAB mediante a composição de uma comissão de implementação, que elaborou suas Diretrizes, em 20083, e de promulgação da lei da sua fundação (Lei n 12.289, de 20 de julho de 2012). Para compreender melhor o que se passa nesse período, em termos de cooperação entre Brasil e África, recorre-se a alguns acontecimentos anteriores à era Lula que possibilitam interpretar a história afro-brasileira e africana numa perspectiva nacional e internacional. Ainda são analisados os termos cooperação Sul-Sul, solidariedade e cooperação solidária para proporcionar uma avaliação crítica e responsável do desenvolvimento da aproximação do Brasil e da África durante o período delineado.

O segundo período que sustenta a análise deste texto é da era Dilma Rousseff, referente a seu primeiro mandato (2010-2014) e ao seu segundo, que inicia em 2014 e é interrompido pelo golpe parlamentar em 2016. Busca-se interpretar a história da cooperação entre Brasil e África, partindo das dinâmicas internas da UNILAB em sua relação com as dinâmicas regionais, nacionais e internacionais. Por isso, dá-se o foco nas sucessivas gestões superiores, as reitorias pro tempore que governaram a universidade.

O último período que o texto leva em consideração é aquele que coincide com o golpe parlamentar contra a presidenta Dilma Rousseff e a nomeação de um reitor pro tempore, oriundo desse processo político conturbador. Tal período é desenhado a partir dos acontecimentos que ocorreram entre 2016 e 2018, tendo a greve de caminhoneiros e eleições em vista como marcadores interpretativos das dinâmicas próprias da UNILAB.

O argumento principal que se defende é que a era petista, constituída de governos Lula-Dilma (2003-2016), foi aquela que melhor possibilitou uma aproximação concreta entre o Brasil e a África. Souza (2018) tem apontado que o uso do termo solidariedade tem sido marca estratégica das relações estabelecidas entre os governos brasileiros e o continente africano. A título de exemplo, pós-golpe, em discurso de transferência de cargo para Aloysio Nunes, José Serra endossa a necessidade de solidariedade na cooperação entre Brasil e África, mas enfatiza a necessidade de algo mais: "Como tenho dito, a África espera de nós mais do que solidariedade ou compaixão: quer parceria, fundada também na convergência

3 UNILAB. Diretrizes Gerais da Universidade da Integração Internacional da Lusofonia Afro-Brasileira, julho de 2010. Disponível em: http://pdi.unilab.edu.br/wp content/uploads/2013/o8/Diretrizes_Gerais_UNILAB. pdf. Acesso em 10 de maio de 2015. 
de nossos interesses e objetivos econômicos e sociais"4. A era Temer tem, portanto, apostado em relações eminentemente econômicas, onde a solidariedade torna-se apenas um discurso falacioso. O que explica essas posições opostas é a concepção ideológica do projeto de nação do Brasil que cada um desses governos carrega, concepções estas que resultam, no caso estudado, em políticas pró ou contra a Universidade da Integração Internacional da Lusofonia Afro-brasileira.

\section{Cooperação internacional para o desenvolvimento: uma proposta teórica pautada num olhar decolonial africano}

Cooperação internacional para o desenvolvimento é uma área de conhecimento que faz parte dos estudos do desenvolvimento. Este último campo de investigação pode proporcionar a realização de estudos disciplinares, multi ou interdisciplinares (FAVREAU; FRECHETTE; LACHAPELLE, 2008; FORSTER, 2007; LOPES, 2005). No caso deste trabalho, privilegia-se uma abordagem interdisciplinar, tendo-se em conta os espaços de trabalhos intelectuais e sociais de seus autores (MALOMALO; FOSENCA; BADI, 2015; MALOMALO, 2017a, 2017b, 2017c; SOUZA, 2015, 2018; SOUZA; LOURAU, 2017).

Entre outros conceitos essenciais aos debates sobre cooperação internacional para 0 desenvolvimento, numa ótica dos agentes que atuam no Sul global, aparecem geralmente estes: cooperação Sul-Sul, cooperação solidária e o desenvolvimento. Para a realização de estudos com marcas decoloniais, recomenda-se que se use sempre criticamente esses conceitos, contextualizando seus usos. Essa é a nossa perspectiva: questionar o uso de conceitos e usá-los numa concepção progressista e libertadora (DUSSEL, 2005; LANDER, 2005).

Os conceitos de cooperação Sul-Sul e cooperação solidária passaram a ser encunhados em meados da década de 1950, fase em que ocorreram vários eventos que versaram a discussão sobre os interesses e problemas em comum dos países recém-

\footnotetext{
4 Ministério das Relações Exteriores. Texto-baseparaodiscursodoMinistro JoséSerraporocasiãodacerimôniadetransmissão do cargo de Ministro das Relações Exteriores - Palácio Itamaraty, 7 de março de 2017. Disponível em: http://www.itamaraty.gov.br/pt-BR/notas-a-imprensa/15830-texto-base-para-o-discurso-de-posse-do-ministro-de-estado-dasrelacoes-exteriores-aloysio-nunes-ferreira-palacio-itamaraty-7-de-marco-de-2018. Acesso em 17 de junho de 2018.
} 
independentes com os países asiáticos (EDMONDSON, 2010; LEITE, 2011). Foram esses eventos que culminaram na conferência de Bandung, em abril de 1955.

A Conferência de Bandung reuniu 29 países africanos e 42 asiáticos. Ela foi e é considerada, até hoje, um marco no despertar dos governos, até então dominados economicamente pelo Norte. Estes países passaram a agir coletivamente na política internacional, defendendo uma agenda própria e totalmente diferente daquela que era subordinada pelos países dominantes. A conferência elencou dez princípios que norteariam suas ações, dentre os quais Leite (2011) cita estes: o respeito aos direitos humanos fundamentais e aos propósitos e princípios da Carta das Nações Unidas; respeito à soberania e à integridade territorial de todas as nações; reconhecimento da igualdade de todas as raças e de todas as nações, grandes ou pequenas; promoção de interesses mútuos e da cooperação; respeito à justiça e às obrigações internacionais.

Essa conferência inspirou o Movimento dos Países não Alinhados, além de fazê-los refletir sobre o contexto de luta contra a dominação política e econômica do Norte contra o Sul, fazendo com que os/as intelectuais, políticos/as e a sociedade civil como um todo da Ásia, da África e da América Latina começassem a construir uma identidade particular, que traduzisse suas experiências como comuns aos povos do Sul.

Eram vários os elementos que identificavam, uniam e mobilizavam esses povos: a colonização, o racismo e a exploração econômica que sofriam e ainda sofrem, por parte dos países do Norte. A colonização a que os países do Sul passaram por séculos foi responsável pelo seu desenvolvimento tardio. Começaram a atuar e tratar de suas ações em termos, como por exemplo, da "cooperação Sul-Sul", que ali já era vista como uma cooperação baseada em princípios de solidariedade, igualdade e soberania entre todos os países envolvidos, de forma a travarem a luta pelo respeito aos direitos humanos e pela condenação do racismo.

Segundo Santos e Meneses (2010), o termo Sul vem a comportar dois sentidos, sendo eles: o Sul geográfico, que leva em conta os países que pertencem ao hemisfério Sul e que foram historicamente colonizados pelos impérios europeus, e o segundo sentido, que compreende o que os autores vão chamar de diversidades epistemológicas existentes no mundo, concebidas pelos autores, como epistemologias do Sul: "O Sul é aqui concebido metaforicamente como um campo de desafios epistemológicos, que procuram reparar os danos e impactos historicamente causados pelo capitalismo na sua relação colonial com o mundo" (SANTOS; MENESES, 2010, p. 19). 
Ainda nesta linha, Edmondson (2010) entende que as cooperações Sul-Sul e solidária são categorias sociais que reivindicam a construção de uma nova ordem mundial econômica que tenha como eixo central a humanização das sociedades.

A pesquisa bibliográfica feita por nós revelou que o melhor caminho para se compreender o uso do conceito da cooperação solidária é investir na gênese e no uso de cada um destes termos, separadamente. Dessa forma, o adjetivo "solidário", fora de seu uso no universo judaico-cristão, tem sido objeto de análise nas ciências humanas no Ocidente. Os textos de Constantino (2009) e Arango (2013) são importantes para a compreensão política e sociológica que o termo solidariedade adquiriu ao longo da História; já o de Wladimir (2007), sendo complementar aos dois outros citados, faz uma ligação entre o termo cooperação e solidariedade quando investiga o sentido da cooperação solidária no contexto da diplomacia e política externa brasileiras com os países do Sul.

Para Arango (2013), a solidariedade tem múltiplos sentidos. Porém, na sua origem, era um conceito jurídico. Somente no século XVIII se imporia o seu uso político na boca do saintsimoniano Pierre Leroux. No século XIX teria uma conotação fatual na pluma de Émile Durkheim que a empregou em dois sentidos: a solidariedade mecânica e a solidariedade orgânica para explicar, sociologicamente, a transformação de uma sociedade tradicional em uma sociedade moderna.

O outro sentido que a solidariedade comporta é a normativa que, conforme Arango (2013), liga-se ao direito romano, que se fundamentava numa forma de obrigação da comunidade responsabilizar-se pelas dívidas de um de seus membros e, inversamente, de um membro responsabilizar-se pelas dívidas de sua comunidade ou família. Para ele, essa concepção da solidariedade recebera novos acrescimentos nos séculos XVIII, com a Revolução Francesa, bem como nos séculos XIX e XX, com a emergência dos movimentos operários, pensadores socialistas, sociais-democratas, defensores de um Estado de Direito e de um Estado de Bem-Estar que garantem os direitos dos cidadãos.

Arango (2013) defende o uso e a prática que combinam a solidariedade fatual com a solidariedade jurídico-normativa. Dito em outros termos, trata-se da defesa de uma solidariedade como responsabilidade comum perante as injustiças estruturais. Esta concepção luta pela implementação de uma democracia social que se expressa no respeito e defesa dos direitos humanos e são fundamentais no plano nacional e internacional. Esse 
modelo é aquele defendido pelos movimentos sociais altermundistas e internacionalistas (FAVREAU; FRECHETTE; LACHAPELLE, 2008).

Segundo Pereira e Medeiros (2015), a Cooperação Sul-Sul, tal que se conhece hoje, iniciou a sua formação histórica no contexto do início da Guerra Fria, com a descolonização afro-asiática e a formação dos primeiros arranjos ligando a periferia global, como a Conferência de Bandung, a criação do Movimento dos Não-Alinhados, do G-77 e da UNCTAD. Nessa primeira fase, para eles, o objetivo era garantir a descolonização e o não-alinhamento. A partir da década de 1970, países da América Latina e África Subsaariana também passam a se envolver, de forma crescente, com a agenda do Terceiro Mundo, em uma tentativa de fomentar a cooperação política, econômica e técnica entre países em desenvolvimento. A Cooperação Sul-Sul passa a ser paulatinamente institucionalizada no âmbito da ONU, sobretudo com a Conferência de Buenos Aires de 1978:

O Plano de Ação de Buenos Aires, resultado das discussões realizadas nessa conferência, desenvolve o conceito de cooperação técnica baseado na reciprocidade e horizontalidade, instrumentalizada através do intercâmbio de conhecimentos, informações, tecnologias e técnicas de gestão em políticas públicas nas áreas de educação, saúde, agricultura, entre outras. O ano de 1978 é um marco na Cooperação Sul-Sul pois pela primeira vez foram elaborados conceitos e princípios de maneira conjunta entre os países periféricos, colocando em destaque a ideia de que a prática social de um país pode ser replicada em outros países e gerar desenvolvimento." (PINO, 2014, p. 66). No sentido de instrumentalizar, organizar e promover a prática da Cooperação Sul-Sul, foi criado o Comitê de Alto Nível para a Cooperação Sul-Sul (órgão subsidiário da Assembleia Geral da ONU), que se tornou uma importante entidade normativa em matéria de cooperação entre países em desenvolvimento (PEREIRA; MEDEIROS, 2015, p. 15).

Devido à nova orientação da política externa brasileira, voltada para os países do Sul e o acúmulo de um trabalho realizado entre 2003 e 2013, a Agência Brasileira de Cooperação $(A B C)$ veio a publicar uma série de guias de orientação sobre a Cooperação Técnica Brasileira. Interessa-nos a definição sobre a Cooperação Técnica Sul-Sul brasileira do Manual de Gestão Técnica da Cooperação Sul-Sul:

A cooperação técnica Sul-Sul é entendida como o intercâmbio horizontal de conhecimentos e experiências originados nos países em desenvolvimento cooperantes. A ideia é compartilhar lições aprendidas e práticas exitosas disponíveis no Brasil, geradas e testadas para o enfrentamento de desafios similares ao desenvolvimento socioeconômico.

(...) Por meio desse trabalho conjunto, busca-se identificar e sistematizar o conhecimento e as competências dos beneficiários da cooperação nos países que fazem parceria com o Governo brasileiro para que, em seguida, tais capacidades sejam aplicadas na geração de soluções locais inovadoras (BRASIL, 2013, p. 13). 
Os princípios de horizontalidade, partilha, trocas, que devem guiar as ações de cooperação sul-sul brasileira, é que nos interessam para as reflexões que estamos a realizar sobre a cooperação solidária entre o Brasil e os países africanos parceiros da UNILAB.

Os trabalhos de Wladimir (2007), Puente (2010) e Leite (2011) nos proporcionam uma oportunidade ímpar para a compreensão das relações entre a cooperação Sul-Sul, a cooperação solidária entre o Brasil e os países do Sul, especialmente os africanos.

Wladimir (2007) pondera que foi a partir dos anos de 1990 para 2000, para ser exato, durante os governos de Fernando Henrique Cardoso (1994-2002) e de Luís Inácio Lula da Silva (2003-2010) que o termo cooperação solidária foi incorporado aos discursos da diplomacia brasileira.

A cooperação e solidariedade, para Wladimir (2007), têm por fundamento a Constituição Brasileira de 1988. Dentro deste documento, o primeiro termo, como instrumento da política externa, aponta para a integração regional com a América do Sul e, hoje, com outras regiões do mundo, como a África.

Quanto ao princípio de solidariedade, durante a reformulação da diplomacia brasileira de 1995 até os sucessivos mandatos de Lula (2003-2010), tornou-se um conceito basilar da cooperação Sul-Sul com a conotação normativa, isto é, como norma jurídica e ética.

A solidariedade concretiza-se na plena liberdade de quem oferece e na de quem recebe. A liberdade autêntica é capaz de se realizar espontaneamente, porque está pronta para compreender necessidades, reconhecer carências e dispor-se à partilha. O desafio com que se defronta, sobretudo no plano internacional, é a defesa do homem, que pressupõe valores éticos, eis que o Homem se encontra no cerne das preocupações da justiça internacional (WLADIMIR, 2008, p. 219).

Esse termo, que faz parte, hoje, dos discursos oficiais da diplomacia brasileira, tem uma origem cristã, e tem inspirado o pensamento social da Igreja Católica e o direito internacional. Funciona como princípio da justiça social para todos, sobretudo os mais necessitados. Significa, também, partilha, trocas que contam com a reciprocidade e o reconhecimento do outro como sujeito histórico. Além disso, conota a ideia do desenvolvimento como liberdade e o uso dos direitos humanos e dos direitos fundamentais como princípios do desenvolvimento humano (SEN, 2000; LOPES, 2005). 
Definir a solidariedade, como acabamos de fazer, não significa que não seja objeto de contestação. Puente (2010) reconhece que o governo Lula tinha plena consciência das acusações, por exemplo, que recebia de seus opositores de que, em vez de investir numa política solidária para os países pobres do Sul, deveria ocupar-se, primeiro, da pobreza que afetava uma parcela da população brasileira.

A política de cooperação internacional brasileira para com o Sul que, desde 2003, definiu-se como cooperação solidária Sul-Sul, tem revelado igualmente suas contradições (MALOMALO, 2014b). Em 2014, Matias de Alencastro chamava a atenção com o título do seu artigo: "Brasil arrisca a sua imagem na África com práticas neocoloniais". Ele não estava fazendo um simples exercício de retórica, pois, antes dele, o trabalho de Schlesinger (2013) ou de Souza Santos (2013) já vinham denunciando a lógica do desenvolvimento extrativista presente no Programa de Cooperação Tripartita Japão-Brasil-Moçambique, conhecido como PROSAVANA.

Trata-se, de fato, de uma ação de cooperação internacional que foge da gramática dos direitos humanos e da solidariedade entre os governos e povos do Sul. A burguesia econômica e a política desses respectivos países criaram uma aliança sagrada para se apoderar de terras de camponeses moçambicanos no corredor de Nacala para alcançar seus interesses, usando-se da força econômica e do poder do Estado, alistando jornalistas, juristas, economistas e intelectuais de direita à sua causa. A sua infelicidade é que os movimentos populares e de agricultores/as moçambicanos da região são bem articulados em nível nacional e internacional. Por isso, têm inibido as ações dos agentes do capital nos seus territórios (VAZ; MALOMALO, 2016; SOUZA; LOURAU, 2017).

Contra a definição de cooperação internacional para o desenvolvimento e da cooperação solidária do paradigma dominante ou do paradigma progressista que servem aos interesses corporativistas e partidários, Malomalo (2014C, 2017C) tem sugerido uma outra concepção do desenvolvimento e de cooperação a partir dos pensamentos africano, afrodiaspórico e de Paulo Freire, seguindo o compromisso da teoria crítica emancipatória.

No lugar de uma filosofia do 'desenvolvimento', Malomalo sugere o uso da filosofia de ubuntu-bisoidade no âmbito das políticas de cooperação internacional. Tanto o pensamento freiriano como o pensamento de ubuntu-bisoidade nos permitem perceber que as forças progressistas, adeptas da pedagogia de esperança e dos/as oprimidos/as, diferentes das forças dominantes, defendem os direitos dos migrantes e das minorias nacionais. 
Para explicar o que ele entende por esperança, Freire chama atenção sobre as forças históricas que produzem a desesperança e a esperança.

Por outro lado, sem sequer poder negar a desesperança como algo concreto e sem desconhecer as razões históricas, econômicas e sociais que a explicam, não entendo a existência humana e a necessária luta para fazê-la melhor, sem esperança e sem sonho. A esperança é necessidade ontológica; a desesperança, esperança que, perdendo o endereço, se torna distorção da necessidade ontológica. Como programa, a desesperança nos imobiliza e nos faz sucumbir no fatalismo onde não é possível juntar as forças indispensáveis ao embate recriador do mundo. Não sou esperançoso por pura teimosia, mas por imperativo existencial e histórico. (...)enquanto necessidade ontológica a esperança precisa da prática para tornar-se concretude histórica. E por isso que não há esperança na pura espera, nem tampouco se alcança o que se espera na espera pura, que vira, assim, espera vã (FREIRE, 1992, p. 5).

A esperança deve ser uma postura cognitiva, estética, política e ética a guiar a práxis de uma educação libertadora.

Uma das tarefas do educador ou educadora progressista, através da análise política, séria e correta, é desvelar as possibilidades, não importam os obstáculos, para a esperança, sem a qual pouco podemos fazer porque dificilmente lutamos e quando lutamos, enquanto desesperançados ou desesperados, a nossa é uma luta suicida, é um corpo-a-corpo puramente vingativo. O que há, porém, de castigo, de pena, de correção, de punição na luta que fazemos movidos pela esperança, pelo fundamento ético-histórico de seu acerto, faz parte da natureza pedagógica do processo político de que a luta é expressão. (FREIRE, 1992, p. 6).

A pedagogia da esperança é um projeto de produção de conhecimento, de estética, linguagens, valores e políticas libertadores que se faz de forma coletiva e solidária. De forma parecida, solidariedade significa, para Freire, um trabalho coletivo para a humanização e, para Malomalo (2017c), ela significa o codesenvolvimento ou desenvolvimento bisoista ou ubuntuista 5 .

Aqui encontramos a sua ligação com a epistemologia da macumba, do ubuntu e da bisoidade. As três epistemologias evocadas pertencem ao que chamamos de epistemologias

\footnotetext{
5 As três epistemologias evocadas fazem parte do trabalho que vem sendo desenvolvido por Malomalo (2014b, 2014c, 2016b, 2017c), no que se refere a produção de conhecimento e trabalho social no campo da educação e de defesa de direitos dos imigrantes africanos/as no Brasil.
} 
negras do Sul global. O seu ponto de partida é a cultura negra, isto é, as bibliotecas africanas e afro-diaspóricas em diálogo crítico com pensamentos culturais filosóficos de outros povos, as forças progressistas de academias e fora das academias, que lutam pela emancipação (MALOMALO, 2016b).

A filosofia do ubuntu e da bisoidade são os pensamentos filosóficos de Ramose (2002; 2011) e de Ntumba (2014). A filosofia da macumba é um empreendimento intelectual que Malomalo (2014b) vem levando a cabo na diáspora brasileira. Todas essas filosofias partem da ideia básica da filosofia tradicional africana de que o mundo é uma teia. Na verdade, é um pluriuniverso ou plurimundo. Em outras palavras, como afirma Ntumba, "o real processual, multiforme e plural" enquanto realidade-total, composta pelas relações estabelecidas historicamente no tempo e espaço entre a comunidade-universo-natureza, a comunidadedo-sagrado-ancestral e a comunidade-de-bantu ou comunidade-de-seres-humanos. Tratase de trilogia constituinte da realidade-processual-total que algumas filosofias chamam do Ser.

O Biso, em Lingala (língua falada na R.D. do Congo) que, junto com Ntumba (2014) traduzimos como o Nós-cósmico ou Nós-ecológico, é um conceito que nos interpela filosoficamente, isto é, desperta nossas consciências no plano intelectual, ético, estético e político para agirmos perante a crise global e da humanidade de forma solidária para com o Outro, isto é, a trilogia constituinte do Nós-cósmico. Esse processo é que nomeamos de macumbização, processo de encanto pelo Outro para se libertar de forma solidária.

Nessa perspectiva, essa filosofia condena o racismo e a xenofobia que as forças liberais, neoliberais e ultradireitistas praticam contra os/as imigrantes e minorias nacionais, ou, ainda, repudia qualquer forma de instrumentalização da cooperação solidária.

\section{Cooperação Brasil-África nos governos Lula (2003-2010)}

Numa perspectiva histórica de curto alcance, as políticas públicas do Estado brasileiro para com a população negra tornam-se compreensíveis quando situadas na agenda nacional e internacional das organizações sociais negras. Entre 1960 e 1970, o Movimento Negro, no Brasil, consolida suas estratégias no seu diálogo com o Movimento de Direitos Civis dos Estados Unidos; os movimentos pan-africanistas e os movimentos de libertação do continente africano. Internamente, a sociedade civil negra, além de estabelecer uma luta 
contra o racismo, com o surgimento da organização social como o Movimento Negro Unificado, trava uma luta, ao lado de outras organizações da sociedade civil, contra a ditadura militar. Algumas figuras negras como Carlos Alberto Caó e Abdias Nascimento participam ativamente da Constituinte, e, em 1988, conseguem fazer aprovar alguns artigos importantes, como o artigo 20 da Lei 7.716/1989, que tipifica o racismo como crime; os artigos 115 e 231, entre outros, revelam que o Brasil se assume como uma nação multicultural, ou seja, onde o Estado se compromete-a proteger os direitos de povos indígenas e afrobrasileiros (MALOMALO, 2017b; D'ADESKY, 2001).

Em 1995, na celebração de 350 anos da morte de Zumbi, as organizações negras, ao perceberem que a situação da população negra continuava deplorável, realizaram em Brasília a "Marcha Zumbi de Palmares contra o Racismo e pela Vida", exigindo o reconhecimento do racismo estrutural por parte do Estado brasileiro, assim como políticas afirmativas para combatê-lo. O governo Fernando Henrique Cardoso (FHC), com o Decreto de 20 de novembro de 1995, cria um Grupo de Trabalho Interministerial com finalidade de desenvolver políticas de valorização da população negra.

Os anos 90 são tidos, numa ala da intelectualidade negra, como o período de debate teórico e político sobre o multiculturalismo, Estado e movimentos sociais. Várias são as soluções propostas: havia, de um lado, o movimento das reparações, que tinha iniciado em São Paulo desde 1993 e, de outro, os grupos que defendiam políticas de cotas e/ou ações afirmativas (FONSECA, 2009). Em 28 de dezembro de 2000, o poder executivo do estado do Rio de Janeiro implementa a Lei $n^{\circ} 3524$, destinando cotas de $50 \%$, no mínimo, do total de vagas oferecidas pelas universidades públicas estaduais, nos respectivos cursos de graduação, aos estudantes que tiveram cursado integralmente os ensinos fundamental e médio em instituições de rede pública dos municípios e/ou do estado. Em 9 de novembro de 2001 sanciona a Lei $n^{\circ} 3.798$, que assegura as cotas raciais, ou seja, $40 \%$ para a população negra e parda nos cursos de graduação da Universidade do Estado do Rio de Janeiro e da Universidade Estadual do Norte Fluminense.

Em 2001, o governo FHC subsidia financeiramente a delegação brasileira para a Conferência de Durban, na África do Sul. As lideranças do Movimento Negro foram em peso e conseguiram eleger uma mulher negra, Edna Roland, como relatora da comissão. Se, para o governo brasileiro, esses gestos eram uma forma de se afirmar nacional e internacionalmente como defensor de direitos humanos, para as organizações negras, 
tratava-se de uma forma de obrigar o Estado brasileiro a assumir a sua responsabilidade para com a população negra num período pós-abolição. Criticado, mesmo sendo contra a política de cotas, mas a favor de políticas de ações afirmativas, cria o programa de ações afirmativas, que consiste na oferta de bolsas de estudos para negros/as nos processos seletivos de diplomatas no Instituto Rio Branco.

Para Malomalo (2017b), no período dos dois mandatos de Lula, pode-se dizer que se começaram a desenhar políticas do Estado em relação à igualdade racial. No setor privado e na sociedade civil, a mesma dinâmica de implementação de políticas públicas de ações afirmativas está em curso. Em 2009, houve a Revisão da Conferência de Durban em Genebra. Mantiveram-se os principais pontos em relação às políticas públicas voltadas para a superação do racismo e discriminação racial da Conferência de 2001.

O advento dos governos de Lula, entre 2003-2010, marcaria uma nova história das políticas públicas para a população negra. A questão racial ocupa a pauta do debate sobre o desenvolvimento nacional. Para tanto, apostou-se na criação da SEPPIR e na promulgação das Lei 10639 e do Estatuto de Igualdade Racial.

A política externa do governo Lula caracterizou-se pela abertura para os países do Sul e teve a ver com a crise política internacional, com a retomada do crescimento da economia mundial e com o lugar que a África veio a ocupar no início do século XXI, a partir do crescimento de suas economias. É neste contexto que este governo brasileiro construiu uma política externa de cooperação Sul-Sul, na qual os países da América Latina e da África, especialmente os Países Africanos de Língua Oficial Portuguesa (PALOP), passaram a ocupar lugar de destaque.

O que as pesquisas mostram é que a África entrou de forma favorável economicamente no século XXI. O PIB continental girava em torno de 5 a $6 \%$. Ademais, o país parceiro do Brasil, a Angola, por exemplo, tinha um PIB que crescia em torno de $20 \%$. O que ocorreu, de fato, no continente, no período de 2000 até 2013 , foi o crescimento econômico e não o desenvolvimento sustentável (SARAIVA, 2012, 2015; PEREIRA; VEIGA, 2011).

A retenção de 2013 serve não somente de parâmetro interpretativo desse texto, mas igualmente por marcar os cinquenta anos de existência da Organização da União Africana (que se transformou em 2001 em União Africana). Nesse período, os chefes de Estados africanos lançaram a Agenda 2063, que visa ao desenvolvimento sustentável inclusivo do continente no prazo de cinquenta anos. Embora se reconheçam os esforços de muitos países 
na superação da pobreza, de conflitos, na realização de reforma da administração pública, na democratização de sua instituição, quando comparado aos anos anteriores aos de 1990, ressalta-se igualmente a dependência de suas economias atreladas à produção e exportação de matérias primas. Por isso, advoga-se a diversificação de suas economias, valorizando a industrialização, o setor de infraestrutura e de tecnologia. Além disso, os Estados africanos vêm sendo orientados para investir no desenvolvimento humano: políticas de igualdade de gênero; formação de mulheres e jovens para a ocupação de um lugar de destaque no mercado de trabalho (CEA/ONU; UA, 2011; UA, 2015).

Os dois governos Lula (2003-2010), que souberam contornar a crise econômica de 2001, encontraram uma África em pleno crescimento econômico. Ademais, buscando consolidar a hegemonia brasileira, por exemplo, na ocupação de um assento no Conselho de Segurança da ONU, no comércio exterior e/ou na criação de uma nova imagem, os governos petistas contavam com o apoio dos países africanos (MALOMALO, 2014C; HELENO, 2014; SARAIVA, 2015).

Vista desse ângulo, a cooperação Sul-Sul no século XXI, embora inspirada pelos princípios de Conferência de Bandung de 1955, dentre outros a solidariedade, o enfrentamento ao colonialismo, combate ao racismo, intercâmbios comerciais justos, serve igualmente aos interesses estratégicos, políticos e econômicos dos países parceiros.

Conforme o relatório de UNCTAD (2010) (Conferência das Nações Unidas sobre o Comercio e Desenvolvimento), intitulado «Desenvolvimento econômico na África. A cooperação Sul-Sul : a África e as novas formas de parceria para o desenvolvimento ",

[t]odos os parceiros do Sul desejam ajudar a África a atender suas necessidades de desenvolvimento, mas existem diferenças significativas no que diz respeito ao interesse comercial ou estratégico que a região apresenta para eles [...]. Por exemplo, Brasil, China e Índia vêem a África como uma importante fonte de recursos naturais necessários para alimentar e sustentar seu crescimento econômico. Eles também vêem a região como um mercado crescente para suas exportações, e estão cada vez mais buscando seu apoio no cenário mundial. A este respeito, a República da Coreia difere do Brasil, da China e da Índia porque o seu compromisso é ditado mais pela necessidade de recursos naturais (petróleo) do que pela necessidade de acesso ao mercado ou apoio político no plano global. Quanto à Turquia esta está mais interessada em encontrar mercados para seus produtos do que em encontrar recursos naturais ou apoio no cenário mundial. (p. 11-12, tradução nossa). 
É dentro deste contexto que se deve compreender a cooperação Sul-Sul brasileira em relação à África e, de forma particular, aos PALOP. Todavia, além dos interesses supra citados, os governos de Lula têm evocado igualmente motivos históricos nos discursos que fundamentam a cooperação solidária.

À criação da UNILAB, Lula chamou de "pagamento de uma dívida histórica" para com os/as africanos/as e seus/as descendentes e, para ele, essa dívida não poderia ser paga com dinheiro, mas com "solidariedade" (INSTITUTO LULA, 2013; SILVA, 2010b). Este termo, cooperação solidária, vem sendo muito usado no contexto da política externa brasileira desenvolvida, principalmente pelo governo Lula, para sinalizar as ações de cooperação internacional com os países do Sul não atreladas às condicionalidades, nem interesses econômicos. Recortamos um trecho da fala do ex-presidente Lula em um programa de rádio em 2010.

\begin{abstract}
Hoje nós temos um estatuto da igualdade racial. Nós temos uma lei que dá mais direito e que recupera a cidadania do povo negro brasileiro. É importante a gente nunca esquecer que nós ficamos 380 anos, sabe, praticando escravidão neste país. O Brasil foi o último país do mundo a abolir a escravidão. Acho que nós temos uma dívida enorme com o continente africano, com o povo africano. Uma dívida que a gente nunca vai poder pagar em dinheiro. [...] a gente vai poder pagar, sabe, em solidariedade, em ajuda humanitária, em ajuda ao desenvolvimento, em ajuda no conhecimento científico e tecnológico. O Brasil tem que ajudar o povo da África. Nós vamos construir uma universidade luso-afro-brasileira na cidade de Redenção, no estado do Ceará, cidade essa que foi a primeira em que houve o movimento pela libertação da escravidão no Brasil. [...] é uma universidade que nós defendemos que ela tenha por volta de dez mil alunos, cinco mil alunos africanos e cinco mil alunos brasileiros. Essa universidade é pra isso. É pra gente formar profissionais. É pra gente fazer uma espécie de pagamento de tributos que nós temos com o continente africano, e ajudar o continente africano (SILVA, 2010a).
\end{abstract}

O trecho citado acima foi recortado da entrevista do presidente Luiz Inácio Lula da Silva concedida à TVNBR durante o seu segundo mandato, no qual relacionou, de forma deliberada, a promulgação do Estatuto da Igualdade Racial e a Lei no 12.289, de 20 de julho de 2010, que instituiu a UNILAB como universidade pública federal. Vemos, no discurso do então presidente, que fica clara a intenção de se realizar algo que, de alguma forma, possa remediar, ainda que minimamente, a participação do Brasil no processo de escravidão dos povos africanos. Uma dívida que deve ser paga com solidariedade. Esta solidariedade seria 
colocada em prática, por meio da fundação da UNILAB, nesta parceria para fins de educação superior com os PALOP e Timor Leste.

Para a efetivação do projeto da UNILAB, foi instalada uma comissão:

A instalação da Comissão de Implantação da Universidade da Integração Internacional da Lusofonia Afro-Brasileira (UNILAB), em outubro de 2008, pelo Ministério da Educação (MEC), deu seguimento a esse esforço [de expansão do ensino superior no país]. E a sanção presidencial da Lei $n^{\circ}$ 12.289, de 20 de julho de 2010, que dispõe sobre a criação da universidade, espelha concretamente essa política (UNILAB, 2010).

A Comissão de Implementação da UNILAB foi instituída pela portaria MEC/ Secretaria de Educação Superior (SESU), № 712, de 9 de outubro de 2008, prorrogada por 180 dias pela portaria MEC/SESU no 1.110 , de 29 de julho de 2009. Compuseram essa comissão: membros do governo, da SEPPIR, do MEC, do Ministério das Relações Exteriores (MRE), da sociedade civil, do movimento negro, das universidades públicas e das agências internacionais, como a Organização das Nações Unidas para a Educação, a Ciência e a Cultura (UNESCO).

A Lei no ${ }^{12.289}$, de 20 de julho de 2010, sancionada por Lula, institui a fundação desta universidade. A UNILAB, nesse sentido, cumpre dupla missão na política do governo Lula: a interiorização e a internacionalização do ensino superior brasileiro. A política de interiorização é parte da política da expansão do ensino superior no Brasil. Para atender a essa demanda, o então governo criou o Programa de Apoio a Planos de Reestruturação das Universidades Federais (REUNI). Com o REUNI, o governo federal adotou uma série de medidas para retomar o crescimento do ensino superior público, criando condições para que as universidades federais promovessem a expansão física, acadêmica e pedagógica da rede federal de educação superior para regiões do interior onde, até então, não se pensava em criar universidades.

A criação da UNILAB corresponde à implantação de políticas de integração da população negra e indígena, historicamente excluída do ensino superior. Embora a Lei de Cotas tenha sido aprovada apenas no governo Dilma, é evidente que havia uma relativa abertura para o diálogo junto aos movimentos sociais, especialmente os movimentos negros, já nos governos Lula. O governo Dilma fez votar a Lei das Cotas (Lei no 12.711/2012), que garante a reserva de 50\% das matrículas por curso e turno nas universidades federais e institutos federais de educação, ciência e tecnologia a alunos oriundos integralmente do ensino médio público em cursos regulares ou da educação de jovens e adultos. Dentro destes 
$50 \%$, os estudantes autodeclarados pretos, pardos e de famílias com renda inferior ou igual a um salário mínimo per capita devem ser contemplados. Os demais 50\% das vagas permanecem para ampla concorrência.

Solidariedade ou dominação? Embora as Diretrizes da UNILAB apontem para concretização da universidade enquanto um mecanismo de desenvolvimento, baseado na solidariedade e reciprocidade, o discurso de Lula aponta mais no sentido do "pagamento de uma dívida" à África. Ou seja, seu discurso evoca mais uma relação de obrigação, uma vez que o Brasil participou ativamente na escravidão de negros/as da África. Mais que isso, percebe-se, também, a necessidade de mostrar um Brasil que busca cooperar com os PALOP como se não houvesse nenhuma relação de troca.

A questão que estamos levantando muito nos preocupa porque, apesar das relações baseadas na cooperação do Brasil para com a África, por um lado, terem gerado muitos avanços em termos de iniciativas como a UNILAB e outros programas de transferência de conhecimento, por outro lado, fica evidente o interesse que o país tem de expandir sua liderança política e ação predatória de empresas brasileiras em países africanos, em que a dualidade da atuação diplomática reflete, além dos limites estruturais para a cooperação internacional, as contradições existentes na sociedade brasileira (HELENO, 2014).

Embora a política internacional do governo Lula tenha se deslocado para o eixo Sul, ele não abandonou os aliados do Norte, apenas ampliou o seu leque de parcerias, dando uma ênfase um tanto maior para os PALOP, Ásia e América Latina.

Em relação à África, a diplomacia brasileira apresenta duas facetas: uma cooperativa, materializada em diversos programas de transferência de conhecimentos, e outra dominadora, revelada pelo interesse brasileiro em expandir sua influência política e pela ação predatória de empresas brasileiras em países africanos [...] Diante de uma aparente contradição (cooperação e dominação), analisamos a política externa do governo Lula (HELENO, 2014, p. 128).

Tanto Heleno (2014) como Leite (2011) vão apontar que as ações tomadas no governo Lula não fogem das demais iniciativas de outros governos brasileiros, inclusive do período ditatorial, que focaram no modelo de desenvolvimento econômico brasileiro, numa lógica capitalista de poder, buscando estreitar a hegemonia nacional. Para isso, o modelo de desenvolvimento brasileiro sempre levou em consideração a promoção de empresas que são 
consideradas "campeãs nacionais" ${ }^{6}$ - termo que, apesar do presidente do Banco Nacional do Desenvolvimento Econômico e Social (BNDES) (2007-2016) renegar, leva em conta os grandes empréstimos e condições generosas dadas a empresas como Andrade Gutierrez, Camargo Correa, Odebrecht, Petrobras, Queiroz Galvão e Vale, que, segundo o Banco Mundial, em dados divulgados pelo Instituto de Pesquisa Econômica Aplicada (IPEA), em 2011, são as principais empresas brasileiras no continente africano, em termos de volume de vendas e investimentos.

O Relatório do Banco Mundial retrata as relações estabelecidas entre estas grandes empresas e a comunidade local como "desenvolvimento de capacidades": "elas tendem a contratar mão de obra local para seus projetos, favorecendo o desenvolvimento de capacidades locais, o que acaba por elevar a qualidade dos serviços e produtos". O mesmo relatório também enfatiza que quase $60 \%$ dos recursos da cooperação técnica brasileira foram destinados para os países africanos em 2010 (IPEA; BANCO MUNDIAL, 2011).

Infelizmente, o relatório não divulga que estas mesmas empresas vêm recebendo diversas críticas devido aos problemas sociais e ambientais que foram criados e vêm sendo agravados pela atuação destas. A Vale, por exemplo, foi alvo de diversas denúncias em Moçambique, isto porque, para sua instalação, chegou a desapropriar diversas pessoas sem nenhuma indenização. Além disso, a Vale, com o apoio dos próprios governos locais, vem utilizando mecanismos de repressão às manifestações sociais dos/as moradores/as locais.

A exemplo da Vale, também esteve a Odebrecht em Angola, que contou, naquela época, com o prestígio do ex-presidente José Eduardo dos Santos7. Estas grandes transnacionais contratam mão de obra local sem condições dignas de trabalho e sem nenhum direito trabalhista. As corporações brasileiras que atuaram e ainda atuam, em diversos países da África, compõem uma elite que vivenciou um processo de grande acumulação de capital

\footnotetext{
${ }^{6}$ As campeãs nacionais são tidas como empresas nacionais de grande porte que possuem forte elemento de presença e expansão para o mercado internacional e que atuam com recursos públicos, que não estão igualmente disponíveis para outras empresas ou setores do país.

7 Para ter mais detalhes sobre a atuação destas corporações em Moçambique e Angola, ver: Radio Mundo Real. A Vale continua perseguindo e criminalizando os lutadores sociais em Moçambique. Disponível em: http://radiomundoreal.fm/6761-as-respostas-das-transnacionais?lang=es. Voa Português. Desalojados moçambicanos acusam Vale de não cumprir promessas. Disponível em: http://www.voaportugues. com/a/moambique-vale-desalojados/3397427.html. Acesso em o3 de maio de 2017.
} 
durante os governos petistas, "contando com o apoio de instituições públicas, financiamento e isenções fiscais" (HELENO, 2014).

A cooperação Sul-Sul/solidária acaba se constituindo enquanto falácia em ímpetos de governança capitalista e predatória, na qual a relação diplomática brasileira é vista como contraditória e muito baseada em interesses econômicos e políticos do Brasil para com estes países do Sul. É o que Visentini (2010) vai chamar de "imperialismo soft", que se traduz numa prática em que muitos países do ocidente, em atitudes imperialistas e colonizadoras, buscam dar novos significados a práticas já antigas, presentes desde a colonização.

Percebe-se também que, de maneira geral, especialmente no caso do Brasil, mas não exclusivamente, pois outros países não fogem à regra, a prática da cooperação solidária não pressupõe relação de ajuda "mútua" em que ambos países envolvidos possam contribuir no desenvolvimento de suas nações. Neste sentido, podemos fazer uso do que Serge Latouche (2004, p. 1) aponta: "Se queremos ajudar alguém é preciso ter também o que pedir em troca. O dom sem contra dom é perverso, é uma forma de vontade de dominação e de arrogância [...] se a África é pobre naquilo que somos ricos, ela se revela rica naquilo que somos pobres."

É evidente que esta cooperação tem trazido benefícios para países africanos, mas, numa lógica perversa, tem beneficiado muito mais as empresas brasileiras instaladas nestes países. Essa relação vertical estabelecida pelos governos brasileiros, inclusive os petistas, tem como consequências drásticas: o mau funcionamento das relações que são estabelecidas a partir destes acordos, como é o caso da UNILAB. A política externa brasileira, a sociedade e a gestão da UNILAB compartilham a ideia de que os/as estudantes africanos/as e timorenses vêm ao Brasil apenas para "consumir" conhecimento. Como se não pudessem contribuir, de maneira igualmente rica, com o desenvolvimento local e da sociedade brasileira.

Veremos, a seguir, de que maneira "solidariedade", o termo chave da cooperação SulSul, é levado em conta na prática de gestão da Universidade e do acolhimento dos discentes africanos. 


\section{Cooperação Brasil-África nos governos Dilma (2010-2016)}

A UNILAB, como projeto de esquerda brasileira, começou a funcionar em 2011, durante o primeiro mandato do governo Dilma Rousseff. Como microcampo político nos auxilia avaliar a política externa brasileira para com a África durante o primeiro e segundo mandato da primeira mulher presidenta da nação.

A UNILAB conheceu três gestões durante os dois mandatos do governo Dilma (20102016). A primeira gestão de Paulo Speller (2011-2013) herdou o boom econômico da era Lula, e isso fez com que a UNILAB recebesse uma atenção especial da parte do MEC e recursos suficientes para a implementação do seu projeto inicial.

Algumas das falhas dessa gestão, do ponto de vista da cooperação internacional solidária são essas: a manobra feita pela reitoria da universidade junto com a cumplicidade do MEC em não publicar o Estatuto da UNILAB, retardando o processo da democratização interna desta instituição internacional - a supremacia branca em todos setores importantes da universidade dificultou para que a gestão da UNILAB tivesse uma marca internacional (MALOMALO, 2018), isto é, incorporasse docentes africanos/as e negros/as brasileiros/as nas instâncias de execução, especialmente nas pró-reitoras; essa gestão falhou na condução de concursos que deveriam atrair profissionais brasileiros/as e dos países africanos especialistas nos assuntos africanos e afro-brasileiros; não conseguiu preencher a cota de $50 \%$ destinados aos estudantes da CPLP, especialmente dos países africanos, sendo uma das razões a não valorização de docentes africanos/as na política de seleção de estudantes estrangeiros/as.

No segundo mandato da presidenta Dilma Rousseff, em 2013, o reitor pró-tempore, Paulo Speller foi nomeado secretário do ensino superior no MEC e, para substituí-lo, na UNILAB, foi indicada Nilma Lino Gomes, que se tornara a primeira mulher negra reitora de uma universidade pública federal no Brasil. O ponto altamente positivo de sua gestão foi o de ter trazido um grupo de intelectuais negros e negras com experiência na militância para dirigir as pró-reitorias de graduação, extensão, arte e cultura e das políticas estudantis e afirmativas.

Embora a lei de cotas tenha sido aprovada desde 2012, no governo Dilma, as sucessivas gestões superiores da UNILAB não fizeram questão de tratar isso como prioridade na seleção de estudantes negros/as brasileiros/as. Essa dificuldade se estende igualmente na lei de cotas em concursos públicos realizados nessa instituição. 
Conforme apontamos anteriormente, o tópico comum da política externa do Brasil para com a África no período Lula e Dilma se caracteriza pelas suas contradições. De um lado, há um discurso progressista de cooperar com a África de forma solidária e, de outro lado, não se cuidou de realizar acompanhamento e monitoramento dos atores do capital nacional brasileiro que atuaram no continente africano. Ademais, se no período Lula havia um dinamismo entre Itamaraty e o continente africano, por exemplo, as constantes visitas feitas pelo presidente Lula durante o seu mandato, nos governos Dilma observa-se um afrouxamento.

Quando Nilma Lino Gomes chegou, uma das primeiras coisas que fez foi dividir a Próreitoria de Graduação e Assuntos Estudantis (PROGRAD) em duas: Pró-reitoria de Graduação (PROGRAD) e a Pró-reitoria de Políticas Estudantis e Afirmativas (PROPAE), com uma Coordenação de Políticas de Ações Afirmativas que comporta dois núcleos: Núcleo de Políticas de Sexualidade e Gênero e Núcleo de Estudos Africanos e Afro-Brasileiros.

Outra falha da gestão Nilma Lino Gomes foi a falta de diálogo com os grupos de estudantes e docentes africanos/as. Isso fez com que houvesse maior peso nas questões afrobrasileiras do que nos assuntos africanos. Essa gestão é aquela que começou a sentir a crise do orçamento no segundo governo de Dilma. A falta do tato político da reitora pro tempore junto ao autoritarismo de alguns membros da gestão superior criaram dificuldades em traduzir para a comunidade estudantil o problema financeiro que o governo estava passando. O resultado de tudo isso é que se cooptou a maioria dos integrantes do Conselho Universitário (CONSUNI), que votou uma resolução que reduzia a entrada de estudantes internacionais de $50 \%$ para $20 \%$.

A crise em emergência, em 2014, teve impactos negativos nas bolsas e auxílios estudantis (NASCIMENTO, 2013; ASSIS, 2014). Dessa forma, os estudantes africanos fizeram a primeira greve, ocupando o campus e exigindo o pagamento de seus auxílios que estavam atrasados. Essa greve criou um conflito interno, dividindo a comunidade acadêmica em dois grupos: o primeiro, de maioria brasileira, branca, junto a uma minoria negra que possuía cargos em setores da gestão; e o segundo grupo, composto de maioria africana e uma minoria brasileira. A crise só acabou com a convocação de uma Assembleia Geral Universitária durante a qual a reitora pro tempore se comprometeu a pagar os auxílios. Ademais, um grupo de docentes exigiu, na ocasião, a publicação do Estatuto e a realização das eleições internas. 
A terceira gestão foi de Tomaz Aroldo da Mota Santos (2015-2016). O seu vice foi um professor cearense e docente do Instituto de Ciências da Natureza e Matemática, Aristeu Rosendo Pontes Lima, nomeado vice-reitor pro tempore quando Nilma Lino Gomes foi convocada, em Brasília, para assumir a SEPPIR. Por ser um jovem inexperiente na gestão de uma universidade internacional, como a UNILAB, ao assumir, um dos seus primeiros atos foi baixar uma resolução que determinava que os/as estudantes, em maioria no Instituto de Humanidades e Letras (IHL), não podiam mais acumular a bolsa permanência e os auxílios que recebiam para sua manutenção, o que logo gerou a maior greve estudantil da história da universidade. A inexperiência mostrou, em muitos outros aspectos, como a incapacidade de diálogo com os/as estudantes, posto que o vice-reitor chamou a polícia para prender os estudantes nacionais e internacionais grevistas. Um grupo de professores e os movimentos sociais locais apoiaram os/as estudantes. A greve só acabou com a vinda do novo reitor pro tempore, Tomaz Aroldo da Mota Santos, que tinha uma longa experiência na gestão de uma universidade pública.

O referido reitor, apesar de agir como um estrategista da política que visa à manutenção do seu poder e do seu grupo, foi um dirigente de diálogo e que mais trabalhou para a institucionalização da UNILAB. Conduziu muitas comissões para dar soluções aos problemas internos, entre as mais importantes pode-se evocar a comissão que trabalhou para a redação de um novo estatuto e regimento e de uma resolução que definisse o lugar do campus fora da sede: Campus dos Malês, na Bahia. A comissão se debruçou para encontrar soluções sobre novas regras de distribuição de auxílios estudantis.

A reitoria de Tomaz Aroldo da Mota Santos, como as outras, não soube capacitar o corpo de servidores para saber lidar com as questões africanas e afro-brasileiras que a UNILAB exige. Em outras palavras, a UNILAB continua sendo dirigida numa perspectiva da hegemonia branca, brasileira e cearense. Docentes africanos/as continuam sendo minoria nas instâncias de poder. O racismo contra estudantes africanos/as dentro e fora da Universidade continua sendo um problema que exige urgência no trato (MALOMALO, 2018; SOUZA, 2018).

Outro elemento grave desse período é que, antes do golpe parlamentar contra o governo Dilma, um setor da universidade sinalizou para a reitoria a necessidade de se realizar uma consulta para eleger um/a reitor/a que fosse docente interno, com a possibilidade de se 
ter candidaturas da gestão e da oposição. Essa sugestão foi negada. Quando veio o golpe, Aroldo foi deposto; o seu vice fez a transição e o MEC nomeou um quarto reitor pro tempore.

\section{Cooperação Brasil-África no governo de Temer (2016-2018)}

A crise global atingiu o seu ápice no Brasil com o golpe parlamentar sofrido pela presidenta eleita nas urnas, Dilma Rousseff, em 2016 (PRONER, 2016a, 2016b; GENTILI, 2016; JINKINGS; DORIA; CLETO, 2016). Em meio à crise política, institucional e econômica, os grupos fascistas e ultranacionalistas revelaram o seu desprezo e racismo contra imigrantes e minorias nacionais.

Na UNILAB, o nacionalismo fundamentalista, além de aparecer em momentos de conflitos de relações interpessoais (MOURÃO, 2016), mostrou-se, também, dentro do processo de impeachment da presidente Dilma, a partir do discurso de um radialista da região de Redenção-Ceará de nome Donizetti, que acusava os /as estudantes africanos/as de serem terroristas, pelo fato de alguns serem muçulmanos/as.

Esses estereótipos estão tanto nas relações verticais estabelecidas pelo Brasil em relação aos PALOP quanto nas motivações interpessoais, cotidianas. A direita brasileira que, além de xenofóbica é racista, vem demonstrando aversão ao projeto UNILAB desde meados de 2016, quando a então presidenta Dilma Rousseff sofreu o inconstitucional impeachment.

O ódio aos projetos e programas sociais criados nos governos petistas sempre foi a marca da direita neoliberal, mas o que se percebe pós-golpe, a partir das ações e discursos dessa elite, é a afirmação de uma branquitude que coloca tudo que não the pertence como inferior, desprezível e passível de ser explorado (MALOMALO, 2017C, 2014a).

Trabalhamos com a hipótese de que as políticas sociais, inclusive aquelas no campo da educação, sempre foram vistas com maus olhos, haja vista que não era a prática nos governos anteriores ao PT. No entanto, após a saída do PT em 2016, de maneira geral, o que se percebe no Brasil, quando remetemos à criação da UNILAB, é o fato de ela ser vista como apenas mais um projeto petista que visa trazer estudantes africanos para estudar "de graça" no Brasil.

Este estado de desinformação a que nos referimos se dá por meios dos conteúdos disseminados pela grande mídia brasileira, que, historicamente, tem sido produto e propriedade da elite nacional e, como tal, vive a serviço da extrema direita. Apoiou golpes e 
encobriu muitas mortes na ditadura militar e, hoje, mais do nunca, tem se colocado a serviço de um governo ilegítimo, que tem tentado, de todas as formas, retroceder direitos historicamente conquistados pelos/as trabalhadores/as brasileiros/as.

Traremos, a seguir, um recorte desse tipo de discurso. Em outubro de 2016, 0 historiador Marco Antônio Villa, professor aposentado da Universidade Federal de São Carlos (UFSCAR) e comentarista da rádio Jovem Pan, proferiu o seguinte discurso em relação à UNILA e UNILAB ${ }^{8}$ :

[...] eu desconheço essa universidade. [...] eu queria saber que relação há entre o Timor Leste, África, o Maciço de Baturité e o Recôncavo Baiano [...] A herança maldita do PT vai durar décadas. No campo da educação, essa universidade é um escândalo [...], portanto, o projeto criminoso do poder petista deixou uma herança maldita em todas as áreas de estrutura do Estado, agora na educação, que herança! Foram criadas dezenas de universidades federais absolutamente inúteis para formar militantes e no caso das que eu citei hoje, são muito graves. [...] MEC deve explicar sobre a Universidade Federal da Integração Latino-Americana [...] universidades "absolutamente inúteis"9 (grifo nosso).

Este foi apenas um trecho de várias falas proferidas pelo então "historiador" que sempre se posicionou contra políticas de ações afirmativas no Brasil. Este contribuiu e ainda contribui para que possamos refletir sobre o ódio que se vivencia na sociedade brasileira, além de uma aversão aos governos petistas e, junto com eles, tudo que pode ter sido criado para atendimento de demandas sociais de populações vulneráveis da sociedade brasileira.

Para Villa, tanto a UNILAB quanto a UNILA são universidades "absolutamente inúteis", já que não ensinam e nem produzem conhecimento, muito pelo contrário, são ideológicas e fazem parte de uma visão de mundo muito precária, que propaga a herança maldita, que ele denomina de "lulopetismo". Ainda pede para que o MEC se posicione quanto

\footnotetext{
${ }^{8}$ Houve igualmente manifestações de alguns agentes dessas universidades, por exemplo: REITOR ELEITO DA UNILAB responde a Marco Villa: Vá estudar! Viomundo, 26/10/202016. Disponível em: https://www.viomundo.com.br/voce-escreve/reitor-eleito-da-unilab-responde-a-marco-villa-vaestudar.html. Acesso em: 26 out. 2016; CARTA ao comentarista Marco Antonio Villa sobre a Unila. Desacato, 19/10/202016. Disponível em: http://desacato.info/carta-ao-comentarista-marco-antonio-villa-sobre-aunila/. Acesso em: 19 out. 2016.

9 JOVEN PAN NEW. Dinheiro público para sustentar curso de "pretagogia" não dá - Marco Antonio Villa. 19/10/202016. Disponível em: https://www.youtube.com/watch?v=M2UaAEWKE-s. Acesso em: 19 out. 2016.
} 
à criação das duas universidades, enfatizando que o Brasil levará pelo menos uma década para se livrar dessa herança maldita.

Tal herança, para Villa, também se resume às dezenas de universidades que foram criadas nos governos petistas e que servem apenas para formar "militantes". Ele ignora completamente o número de jovens, inclusive jovens negros/as, que ingressaram no ensino superior público desde os anos 2000, por meio do sistema de cotas sociais e raciais, implantado nos governos Lula e Dilma.

Ainda que, com todas as críticas que temos aos governos petistas, não podemos negar os avanços na educação superior e, neste campo, temos a UNILAB. E nela está o nosso grande desafio, que é ver o projeto dar certo, tendo em conta o que ele representa em termos de alianças historicamente construídas para com o continente africano, a Ásia ${ }^{10}$ e a América Latina.

Kally (2001) nos apontou que a vinda de imigrantes africanos sempre foi dificultada. E, a exemplo desta afirmativa, temos a Constituição de 1934, que, segundo Medeiros (2013), é considerada a mais racista pelos estudiosos devido a afirmar que a educação no país deveria seguir os princípios da eugenia, estabelecendo cotas de imigrações baseadas no número de pessoas vindas de determinados países nos últimos cinquenta anos (países europeus, especialmente).

Ou seja, houve ações afirmativas para imigração europeia (branca) no Brasil que não geraram os mesmos embates que essa iniciativa de ação afirmativa para imigração estudantil africana e do Timor Leste proposta por Lula, ou, até mesmo, as ações afirmativas com critérios raciais para que a população negra e indígena brasileira possa ter acesso ao ensino superior público no Brasil.

O Brasil, como vemos claramente e não muito diferente de diversos países do mundo, sempre escolheu o tipo de cidadão/ã que deveria, conforme seus interesses, compor o país. E, como salienta Castro (2005), vivemos em tempos de violações de princípios mínimos de respeito ao humano, em que imigrantes, principalmente os/as negros/as, são constantemente criminalizados/as.

\footnotetext{
${ }^{10}$ No caso da Ásia, apenas Timor Leste têm sido contemplado enquanto país que faz parte da UNILAB.
} 
A atual gestão de Anastácio de Queiroz Souza iniciou em 2016 junto com o golpe parlamentar. Chegou num ambiente de divisão interna, tendo, de um lado, o grupo do antigo reitor pro tempore, à exceção do vice, que pediu a demissão, que trabalhava pela manutenção do seu poder e, de outro lado, o grupo da oposição, desmoralizado pelo fato de não conseguir legitimar, através do CONSUNI, a consulta informal que tinha realizado. Esta, inicialmente, contou com o apoio do Sindicato da UNILAB (SINDUNILAB), que auxiliou em montar uma comissão que cuidou do todo processo de consulta posterior.

A criminalização do projeto UNILAB deu seus indícios na gestão antidemocrática da própria universidade, desde a mudança de governo, com novo reitor pró-tempore, Anastácio de Queiroz Sousa. Em 05 de julho de 2017 foi publicado um aditivo que alterava o edital 17/2017, que tratava sobre o processo seletivo em andamento de estudantes estrangeiros/as para ingresso nos cursos de graduação da UNILAB.

O aditivo em questão buscava cancelar a demanda orçamentária que vinha garantindo, até então, a assistência material do Programa Nacional de Assistência Estudantil (PNAES) para estudantes internacionais ingressos na universidade por meio do processo seletivo em seus países de origem. O cancelamento dessa política de permanência é o desmonte de todo o projeto de internacionalização e integração com a África e Timor Leste. Devido à pressão da comunidade acadêmica, a medida foi revogada. Mas não temos a garantia de como vem se efetivando a prática desses processos seletivos nos países em questão.

Temos percebido que uma parcela de docentes ligados aos partidos e aos movimentos sociais de esquerda passaram a apoiar a gestão de Anastácio de Queiroz Sousa, vislumbrando permanecer nos cargos de poder da universidade, quando esse sair. Dessa forma, nesse tempo de incertezas, os campi da UNILAB no Ceará vêm sendo geridos no jogo perigoso dos interesses egoísticos e corporativos e no jogo do poder pelo poder. O campus dos Malês, implementado em 2014, em São Francisco do Conde, na Bahia, por não ter poder de barganha, é visto pelo reitor pro tempore atual como um gasto inútil e deve ser, para ele, anexado à Universidade Federal da Bahia.

A situação que a UNILAB vem sofrendo corresponde à conjuntura mais ampla, que se relaciona às posturas neoliberais que vêm sendo tomadas pelo atual governo de Michel Temer, em relação ao ensino superior público no país. Na era Temer, as universidades públicas brasileiras, principalmente aquelas criadas nos governos petistas, vêm sofrendo 
cortes constantes que ameaçam a permanência de estudantes pobres, negros, indígenas e quilombolas.

Em 29 de maio de 2018, estudantes indígenas e quilombolas estiveram em uma reunião com o ministro da educação, Rossieli Soares, que informou que, para este ano, a proposta do Ministério da Educação é de apenas 800 bolsas. A medida, como podemos ver, só demonstra a falta de interesse do governo em garantir a permanência destes/as estudantes nas universidades federais do país. Estudantes que ingressaram nas universidades federais em 2018 estão até agora sem receber a bolsa e só ficaram sabendo da medida após pressionarem o MEC para que respondessem sobre os benefícios que não estão sendo ofertados aos novos estudantes. Para Luana Kumaruara, aluna indígena de antropologia da Universidade Federal do Oeste do Pará (UFOPA):

O ministro nos trouxe até Brasília para ser frio, ríspido, não se dispor a ouvir as demandas e saber das realidades. Veio só para dar a decisão que já estava tomada e dizer que precisava sair para reunião com Temer. Não veio para um diálogo, somente para uma imposição [...] essa reunião mostra os retrocessos nos nossos direitos, onde se tenta atacar uma política já garantida. Saímos frustrados com a decisão. Essa política de ação afirmativa foi criada para atender uma vulnerabilidade, como fazer distinção de quem é vulnerável ou não entre os vulneráveis? ${ }^{11}$

O descaso apontado por Luana evidencia o tipo de prioridade do atual do governo. Em 30 de maio, um dia após a declaração do corte/redução de bolsas permanência para indígenas e quilombolas, o governo adota a Medida Provisória 839, que concede o crédito de 9,58 bilhões no ministério de Minas e Energia e Defesa optando, dessa forma, por dar continuidade a uma política de preços que só tem favorecido e sustentado os interesses do mercado. O governo de Temer vai bancar a privatização e as forças armadas brasileiras com

\footnotetext{
${ }^{11}$ GAVALLI, Guilherme. MEC oferece apenas 800 bolsas e ameaça permanência de 4 mil indígenas e quilombolas na universidade. Desacato. 02/06/2018. Disponível em: http://desacato.info/mec-oferece-apenas-8oo-bolsase-ameaca-permanencia-de-4-mil-indigenas-e-quilombolas-na-universidade/. Acesso em o2 de junho de 2018. O fato do MEC autorizar o pagamento de 2,5 mil bolsas não modifica o foco da nossa argumentação que é salientar a política neoliberal do governo atual: Cf. MEC autoriza 2,5 mil bolsas para indígenas e quilombolas. Agência Brasil. 15/06/2018. Disponível em: http://agenciabrasil.ebc.com.br/educacao/noticia/2018-06/mec-autoriza-25-mil-bolsas-para-indigenas-equilombolas. Acessado em 15 jun. 2016.
} 
o corte de orçamento que afeta áreas e programas dirigidos às populações mais vulneráveis do país.

Ações afirmativas, obviamente, como se pode ver, não são prioridade, políticas de permanência, menos ainda. Soma-se o fato de que tanto os/as índios/as, como suas terras, já não eram prioridade nos governos anteriores, e o cenário é o mesmo para a população pobre e negra do país. As políticas públicas de cuidado para com as mulheres, negros/as, indígenas, quilombolas, migrantes, população LGBTQI12 jovens e usuários de drogas vão sendo cada vez mais sucateadas.

\section{Considerações finais}

Retomando algumas considerações feitas por Malomalo (2018) na revista Sures, nossa avaliação é que, no nível micro da cooperação Brasil-África, os desafios que a UNILAB enfrenta e que, ao serem enunciados comportam germes de suas soluções, podem se traduzir da seguinte forma: o maior desafio é encontrar dirigentes e servidores/as comprometidos/as com o projeto original. Tivemos alguns avanços nas primeiras três gestões comandadas por dois reitores e uma reitora pro tempore indicados pelo PT. Cada gestor que trabalhou, no período de 2010 até o golpe de 2016-2017, teve suas qualidades, porém, o que mais atrapalhou foi a "politicagem": fazer a política para se manter no poder ou almejando outros interesses, usar o poder para servir a alguns grupos de interesses.

Os interesses particulares ou corporativos têm atrapalhado a concretização do projeto da UNILAB. O que temos observado é que a aprovação do estatuto da universidade foi feita para assegurar que aqueles que estão no poder ali permaneçam. A universidade virou uma fábrica de reitores pro tempore. O que está posto é que os governos e os partidos políticos, em cumplicidade com seus reitores indicados e seus grupos de interesse, usaram e usam da UNILAB como arena da manutenção de seu poder. Só será possível mudar isso com eleições que devem permitir à comunidade interna escolher seus/suas dirigentes detentores/as de um plano de gestão comunitário pautado na filosofia do Ubuntu, por exemplo.

\footnotetext{
${ }_{12}$ A sigla LGBTQI - em termos de luta dos movimentos sociais, vem ganhando força, já que inclui além de orientação sexual e diversidade de gênero a perspectiva teórica e política dos Estudos Queer.
} 
O dinheiro investido na universidade, desde o início, foi muito mal aproveitado para cumprir com o projeto de construção de prédios da UNILAB. Impera nas Diretrizes a ideia de que a arquitetura da universidade deveria se inspirar nas culturas africanas e indígenas. Mas o que foi construído foram os prédios de sempre: concretos que representam a filosofia desenvolvimentista. Os problemas que temos nesses aspectos são graves: as residências estudantis estão em atraso; as construções são feitas com poucos cuidados com o meio ambiente: faltam árvores, por exemplo.

Deixou-se de cuidar dos concursos públicos na seleção de profissionais, docentes e TEAs. Dessa forma, a UNILAB colocou dentro de si seus/suas inimigos/as, pessoas que trabalham para destruí-la. Essa destruição se manifesta pelo desejo de algumas pessoas em vê-la anexada à UFC, ou, ainda, nos discursos racistas que desejam a não permanência de estudantes estrangeiros/as. Como os processos seletivos já foram feitos, cabe à Reitoria, conjuntamente com os colegiados dos Institutos, sindicatos de docentes e TEAs, pensar em cursos de qualificação para os/as concursados/as numa perspectiva intercultural e da cooperação solidária.

Descuidou-se, desde a implementação da UNILAB, da política preventiva em torno dos direitos do meio ambiente, da cidade, da segurança e da diversidade. Os Governos e as Reitorias pro tempore deixaram de planejar a implementação de uma universidade nos interiores do Ceará e da Bahia, concomitantemente com o planejamento urbano de cidades que receberam seus membros. De 2011 até 2018, as cidades de Redenção e Acarape passaram a receber mais de quatro mil pessoas. A criação de uma cidade internacional, com esse número de pessoas, exige ações conjuntas de dirigentes da UNILAB com os chefes de executivos dos governos federais, estaduais e municipais: investimentos na política de mobilidade, na segurança, na infraestrutura, no lazer e, especialmente, nas políticas de diversidade étnico-racial e de gênero. Sem isso, os estudantes brasileiros/as e estrangeiros/as continuarão a vivenciar situações de negação de seus direitos de cidadania, o racismo na universidade e fora dela ${ }^{13}$.

\footnotetext{
${ }^{13}$ Ler os trabalhos de Langa, Ercílio Neves Brandão. Diáspora Africana no Ceará no Século XXI: ressignificações identitárias de estudantes imigrantes- 2016 - Tese; Souza, Osmaria Rosa. Pensando os direitos de cidadania dos/as estudantes africanos/as no Brasil: estudo de caso sobre a política de assistência estudantil na Universidade da Integração Internacional da Lusofonia Afro-Brasileira (2010-2017) 2018 - Dissertação
} 
Há pouca valorização (dos que já são poucos/as) professores/as negros/as africanos/as nas instâncias de gestão e nos processos seletivos da universidade. É preciso que a política de cotas na sua dimensão internacional seja cumprida. Caso contrário, construiremos uma universidade internacional com cabeças-pensantes nacionais. A mesma política de cotas deve ser praticada nos processos seletivos de estudantes estrangeiros/as. Talvez a crise econômica e política atual sinalize que o Estado brasileiro deve criar um fundo conjunto com a CPLP e, para ser ainda mais radical, com a União Africana (UA) para assegurar uma gestão multilateral. Assim, poderemos superar os desafios de auxílios e bolsas estudantis. Ao dizer isso, reconhecemos que o governo brasileiro deve abandonar a sua política neoliberal atual, que é inimiga declarada da cooperação internacional solidária entre as nações do Sul.

O último desafio é da gestão entre a Sede do Ceará e o Campus dos Malês da Bahia. Os problemas que nós enfrentamos são vários: precariedade na infraestrutura, uma péssima comunicação entre setores do Ceará com os da Bahia, falta de investimento dentro de um potencial enorme que o recôncavo baiano comporta, falta de diálogo com os países africanos. Em suma, há a inexistência de uma cultura de se trabalhar num ambiente internacional, intercultural e inter-regional. Uma universidade como a UNILAB exige a prática de uma outra gestão pública.

Não se trata de pautar a sua ação nos cortes, pois é preciso responsabilidade e compromisso com essas novas realidades que só a UNILAB tem: o internacional no interior. Estamos falando de gestão de gente pautada na gramática de direitos humanos e de povos. Tal gestão tem a dignidade humana como centro. Nossa autoavaliação se pauta no fato de que, em muito, a UNILAB avançou, mas ainda é preciso que almejemos sua consolidação e sucesso.

Ubu-ntu afirma Ramose (2011) é o "Ser-Sendo". Isto é o Ser que se move para outros Seres. A concepção africana do mundo e da vida, como uma abertura para com o Outro, coloca-se como um princípio epistemológico, ético, estético e político para a superação da crise atual.

Quando se pensa o mundo atual nessa perspectiva coletiva e solidária, a desesperança, de que nos falou Freire (1992), o egoísmo, o racismo e a xenofobia deixam de ganhar a centralidade. O medo deixa lugar à esperança. A esperança como realidade ontológica ocupa o centro em nossas lutas epistemológicas e políticas para a defesa dos direitos dos/as imigrantes e para o futuro da cooperação Brasil-África. Fazer isso é construir 
um mundo melhor para o Biso-Cósmico, a comunidade planetária cujos humanos fazem parte. Trata-se da vitória da razão cosmopolita intercultural sobre a razão indolente capitalista.

A pedagogia da esperança rima com a epistemologia de aposta de que nos fala Boaventura de Souza Santos (SANTOS; MENESES, 2010). Apostar em nós mesmos, nesses tempos de crise, como agentes transformadores; apostar nos/as políticos/as progressistas que, apesar dos erros que cometem, possam vir a superá-los.

A UNILAB, para nós, continua sendo outro espaço intercultural e inter-racial onde as contradições das políticas de cooperação e de integração de povos estruturam-se numa lógica de tensão (SOUZA; MALOMALO, 2016). As estratégias de nossas lutas, apesar de suas contradições, devem nos tornar semeadores/as da esperança e não do ódio. A nossa aposta tem que ser mais alta aqui, uma vez que se trata de um espaço de excelência onde se educa jovens brasileiros/as, africanos/as e timorenses a lutar contra todos os tipos de dominação, contra o colonialismo, neocolonialismo, racismo, machismo, homofobia e a destruição do universo e da natureza.

\section{Referências}

ALENCASTRO, Matias de. Brasil arrisca a sua imagem na África com práticas neocoloniais. Folha São Paulo, 2014. Disponível em: http://www1.folha.uol.com.br/ mundo/2014/08/1507830-analise-brasil-arrisca-sua-imagem-na-africa-com-praticasneocoloniais.shtml. Acesso em: 29 agos. 2014.

ARANGO, Rodolfo. Solidaridad, responsabilidad, injusticia estructural, democracia, derechos humanos, derechos sociales. Revista de Estudios Sociales, n. 46, 2013, p. 216.

ASSIS, A. C. L. et. al. As políticas de assistência estudantil: experiências comparadas em universidades públicas brasileiras. Revista GUAL, v. 6, n. 4, p. 125-46, ed. esp. 2013.

BRASIL. Manual de Gestão da Cooperação Técnica Sul-Sul. Brasília: Edição da ABC, Agência Brasileira de Cooperação, Ministério das relações externas, 2013.

CASTRO, Mary G. Estranhamentos e identidades Direitos humanos, cidadania e o sujeito migrante Representações em textos diversos. Revista Brasileira de Estudos

Populacionais. São Paulo, v. 22, n. 1, p. 5-28, jan./Jun. 2005

CONSTANTINO, Alexandre Krügner. Solidariedade: entre o desencanto e o reencanto. Campinas, SP: Universidade Estadual de Campinas/ Instituto de Filosofia e Ciências Humanas, 2009. (Tese de doutorado). 
D'ADESKY, Jacques. Pluralismo étnico e multiculturalismo: racismo e anti-racismo no Brasil. Rio de Janeiro: Pallas, 2001.

DUSSEL. Henrique. Transmodernidade e transculturalidade (Interpretação desde a Filosofia da Libertação). In: FORTNET-BETENCOURT, Raul. Interculturalidade: Críticas, diálogos e perspectivas. São Leopoldo: Nova Harmonia, 2004, p. 159-208.

EDMONSON, Locksley. África e as regiões em via de desenvolvimento. In: MAZRUI, Ali A.; WONDJI, Christophe (ed.). História geral da África, VIII: África desde 1935. Brasília: Unesco, 2010, p. 1003-1051.

FAVREAU, Louis; FRECHETTE, Lucie; LACHAPELLE, René. Coopération Nord-Sud et développement : Le défi de la reciprocité. Québec: Presse Universitaire du Québec, 2008.

FONSECA, José Dagoberto. Políticas públicas e ações afirmativas. São Paulo: Editora Selo Negro. Coleção Consciência em Debate, 2009.

FORSTER, Jacques. Pertinece des études du développement à l'ère de la mondialisation. Genève: IUED, 2007, p. 11-19. Etudes du développement pour demain. Disponível em: <http://www.ived.unige.ch>. Acesso em: 25 ago. 2007.

FREIRE, Paulo. Pedagogia da esperança: um encontro com a pedagogia do oprimido. Rio de Janeiro: Paz e Terra, 1992.

FREIRE, Paulo; GUIMARÃES, Sérgio. A África ensinando a gente: Angola, Guiné-Bissau, São Tomé e Príncipe. Rio de Janeiro: Paz e Terra, 2003.

FREIRE, Paulo; FREIRE, Nita; OLIVEIRA, Walter Ferreira de. Pedagogia da solidariedade. Indaiatuba/SP: Villa das Letras, 2009.

GAVALLI, Guilherme. MEC oferece apenas 800 bolsas e ameaça permanência de 4 mil indígenas e quilombolas na universidade. Desacato. 02/06/2018. Disponível em: < http:/l desacato.info/mec-oferece-apenas-8oo-bolsas-e-ameaca-permanencia-de-4-mil-indigenas -e- quilombolas-na-universidade/>. Acesso em: 02 jun. 2018.

GENTILI, Pablo (Ed.). Golpe en Brasil: Genealogía de uma farsa. Ciudad Autónoma de Buenos Aires: CLACSO; Buenos Aires: Fundación Octubre; Buenos Aires: UMET, Universidad Metropolitana para la Educación y el Trabajo, 2016. Disponível em: http://biblioteca.clacso.edu.ar/clacso/se/20160624045419/GolpeEnBrasil.pdf. Acesso em: 20 jun. 2017.

HELENO, Gorjão Bezerra. A política externa do Governo Lula: A experiência da Universidade da Integração Internacional da Lusofonia Afro-Brasileiro (Unilab). Fortaleza: UECE, 2014 - Dissertação de mestrado.

INSTITUTO LULA. "Perspectiva da Unilab é cooperação internacional solidária", diz reitor. 08 nov. de 2012. Disponível em: http://www.institutolula.org/perspectiva-da-unilab-ecooperacao-internacional-solidaria-diz-reitor/\#.UysGg_IdWSo. Acesso em: og de out. 2013. 
IPEA; BANCO MUNDIAL. Ponte sobre o Atlântico Brasil e África Subsaariana: parceria Sul-Sul para o crescimento. Brasília, 2011. Disponível em:

http://www.ipea.gov.br/portal/index.php?option=com_content\&view=article \&id=12637 Acesso em: 26 mar. 2017.

JINKINGS, Ivana; DORIA, Kim; CLETO, Murilo (Orgs). Porque gritamos golpe? Para entender o empeachment e a crise política no Brasil. São Paulo: Boitempo, 2016.

KALY, Alain Pascal. O Ser preto africano no "paraíso terrestre": Um sociólogo senegalês no Brasil. Lusotopia, 2001, p. 105-121. Disponível em:

http://www.lusotopie.sciencespobordeaux. fr/resu10006.html. Acesso em: 25 set. 2011.

LATOUCHE, Serge. A África pode contribuir para resolver a crise do ocidente? Tradução: Acácio Sidinei Almeida Santos. Espaço Plural, v. 14, n. 28, p. 175-197, 2004.

LANDER, Edgardo (Comp.). La colonialidad del saber: eurocentrismo y ciências sociales: Perspectivas latino-americanas. Bueno Aeres: CLSCSO, 2005.

LEITE, Patrícia Soares. O Brasil e a cooperação Sul-Sul em três momentos de política externa: os governos Jânio Quadros/João Goulart, Ernesto Geisel e Luiz Inácio Lula da Silva. Brasília: Fundação Alexandre de Gusmão, 2011.

LOPES, Carlos. Cooperação e desenvolvimento humano: A agenda emergente para o novo milênio. São Paulo: UNESP, 2005.

LOPES, Carlos; THEISOHN, Thomas. Desenvolvimento para céticos: Como melhorar o desenvolvimento de capacidades. São Paulo: Unesp, 2006.

MALOMALO, Bas'llele. UNILAB e os desafios futuros - entrevista de Samuel Santos. SURES, n. $11-2018$, p. 1-8. Disponível em: https://revistas.unila.edu.br/sures/ issue/view/55. Acesso em: 8 jun. 2018.

MALOMALO, Bas'llele. Repensar o multiculturalismo e o desenvolvimento no Brasil: políticas públicas de ações afirmativas para a população negra (1995-2009). v. 1 - Porto Alegre: Editora FI, $2017 a$.

MALOMALO, Bas' llele. Repensar o multiculturalismo e o desenvolvimento no Brasil: políticas públicas de ações afirmativas para a população negra (1995-2009). v. 2 - Porto Alegre: Editora FI, 2017b.

MALOMALO, Bas'llele. Crise internacional: Migrações africanas, cooperação e esperança. In: MALOMALO, Bas'llele; MARTINS, E.; FREIRE, J. África, migrações e suas diásporas: Reflexões sobre a crise internacional, cooperação e resistências desde o Sul. Porto Alegre: Editora Fi, 2017c, p. 21-52.

MALOMALO, Bas'llele. Branquitude como dominação do corpo negro: diálogo com a sociologia de Bourdieu. Revista da ABPN, v. 6, n. 13, mar.-jun. 2014a, p. 175-200.

MALOMALO, Bas'llele. Filosofia do Ubuntu: Valores civilizatórios das ações afirmativas para o desenvolvimento. Curitiba: CRV, 2014b. 
MALOMALO, Bas'llele. A integração Brasil-África: uso e sentido da cooperação solidária nos discursos de Luiz Inácio Lula da Silva. In: FREITAS, Raquel Coelho de; MACHADO SEGUNDO, Hugo de Brito (Orgs.). Democracia, equidade e cidadania. Curitiba: CRV, 2014 c, p. 70-91.

MALOMALO, Bas'llele. FONSECA, José Dagoberto; BADI, Mbuyi Kabunda (Org.). Diáspora africana e migração na era da globalização: experiências de refúgio, estudo, trabalho. Curitiba: CRV, 2015.

MALOMALO, Bas'llele. Mobilização política dos imigrantes africanos no Atlântico Sul pela conquista de direitos em São Paulo: o caso da morte da Zulmira em 2012. Revista Crítica Histórica, Ano VII, nº 13, junho/2016a, p. 1-26.

MALOMALO, Bas'llele. Macumba, macumbização e desmacumbização. In: SILVEIRA, Ronie Alexsandro Teles da; LOPES, Marcos Carvalho (Orgs.) A religiosidade brasileira e a filosofia. Porto Alegre, RS: Editora Fi, 2016b, p. 132-16o.

MEDEIROS, C.A. Brasil, Estados Unidos e a questão racial: a fertilidade de um campo cheio de armadilhas, in PAIVA, Angela R. (org.). Ação afirmativa em questão: Brasil, Estados Unidos, África do Sul e França. Rio de Janeiro: Pallas, 2013, p. 241-265

MOURÃO, Daniela Ellery. Entre Palmares E Liberdade: Reconfigurações identitárias de estudantes africanos $\mathrm{Na}$ Unilab. Trabalho apresentado na $30^{\mathrm{a}}$ Reunião Brasileira de Antropologia, realizada entre os dias 3 e 6 de agosto de 2016, João Pessoa/PB.

NASCIMENTO, Clara Martins do. Assistência estudantil consentida. Disponível em: http://www.andes.org.br/andes/print-revista-conteudo.andes?idRev=41\&amp;idArt=211. Acesso em: 20 jun. de 2013.

NTUMBA, Tshamalenga $M$. Le réel comme procès multiforme : pour une philosophie du Nous processuel, englobant et plural. Paris : Edilivre-Aparis, 2014.

PEREIRA, Katarina da Costa; VEIGA, Pedro da Motta. O Brasil frente à emergência da África: comércio e política comercial. Julho de 2011. Disponível em:http://www.cindesbrasil.org/site/index.php?option=com_jdownloads\&ltemid=14\&view $=$ finish \&cid $=545 \&$ catid $=7-$. Acessado em: 16 jun. 2014 .

PEREIRA, Analúcia Danilevicz; MEDEIROS, Klei. O prelúdio da cooperação sul-sul: da Conferência de Bandung à Conferência de Buenos Aires (1955-1978). I Seminário Internacional de Ciência Política Universidade Federal do Rio Grande do Sul, Porto Alegre, Set. 2015, P. 1- 21. Disponível em: https://www.ufrgs.br/sicp/wpcontent/uploads/2015/og/PEREIRA-MEDEIROS-2015-O-Prelúdio-Da-Cooperação-SulSul.pdf. Acessado em 18 ago. 2018.

PRONER, Carol et al. A resistência ao golpe de 2016. Bauru/SP: Canal 6, 2016a. PRONER, Carol et al. A resistência internacional ao golpe de 2016. Bauru/SP: Canal 6, $2016 \mathrm{~b}$. 
PUENTE, Carlos Alfonso Iglesias. A cooperação técnica horizontal brasileira como instrumento de política externa: a evolução da cooperação técnica com países em desenvolvimento - CTPD- no período 1995-2005/Carlos Alfonso Iglesias Puente. - Brasília: FUNAG, 2010.

SANTOS, B; MENESES, M. (Orgs.). Epistemologias do Sul. 2 ed. - São Paulo: Cortez, 2010.

SANTOS, B; MENESES, M. Direitos humanos, democracia e desenvolvimento. São Paulo: Cortez, 2013.

SARAIVA, José Flávio Sombra. África parceira do Brasil atlântico: relações internacionais do Brasil e da África no iníclo do século XXI. Belo Horizone: Fino Traço, 2012.

SARAIVA, José Flávio Sombra. África no século XXI: um ensaio acadêmico. Brasília: FUNAG, 2015.

SCHLESINGER, Sérgio. Cooperação e investimento do Brasil na África: o caso do ProSavana em Moçambique /Sergio Schlesinger, - $1^{\text {a }}$ ed. FASE, Maputo, 2013.

SEN, Amartya. Desenvolvimento como liberdade. São Paulo: Companhia das Letras, 2000.

SILVA, Luís Inácio Lula da. Café com o presidente: Uma universidade para brasileiros e africanos construída no Brasil. Entrevista concedida na RNB em 27 de julho de $2010 a$. Disponível em: https://www.youtube.com/watch?v=QBGkEml-I_s. Acesso em: 07 de março de 2014 .

SILVA, Luís Inácio Lula da. Discurso - O Brasil tem política de solidariedade para a África. Fórum Social Mundial, Porto Alegre, 26 de janeiro de 2010b. Disponível em: http://www.youtube.com/watch?v=MWFmE7JgYso. Acesso em: og de out. 2013.

SOUZA, Lorena Francisco de. Migração para qualificação da força de trabalho e a questão racial: Estudantes africanos/as lusófonos/as negros/as em universidades goianas. Tese de doutorado. Departamento de Geografia. São Paulo, FFLCH-USP, 2014.

SOUZA, Osmaria Rosa; MALOMALO, Bas'llele. Universidade da Integração Internacional da Lusofonia Afro-Brasileira e os desafios da integração perante o racismo contra os/as estudantes africanos/as no Ceará. Interfaces Brasil/Canadá. v. 16, p. 256 - 293, 2016.

SOUZA, Osmaria; LOURAU, Julie. Cooperação Sul-Sul e a Universidade da Integração Internacional da Lusofonia Afro-Brasileira: Solidariedade ou dominação? In MALOMALO, B.; SIMÃO, E.M.; FREIRE, J.S.M. (Orgs.), África, migrações e suas diásporas. Porto Alegre: Editora Fi, 2017, p. 53-74.

RAMOSE, Mogobe. Sobre a legitimidade e estudo da filosofia africana. In: Ensaios Filosóficos, v. IV - outubro/2011, p. 9-25. Disponível em: http://www.ensaiosfilosoficos .com.br/Artigos/Artigo4/RAMOSE MB.pdf. Acesso em: 17 fev. 2016. 
RAMOSE, Mogobe. A ética do ubuntu. Tradução para uso didático de: RAMOSE, Mogobe B. The ethics of ubuntu. In: COETZEE, Peter H.; ROUX, Abraham P.J. (eds). The African Philosophy Reader. New York: Routledge, 2002, p. 324-330, por Éder Carvalho Wen.

UNCTAD - Conférence des Nations Unies sur le Commerce et le Développement. Le Développement Économique en Afrique - Rapport 2010: La Coopération Sud-Sud:

L'Afrique et les nouvelles formes de partenariat pour le développement. New York/Genève: Nations Unies, 2010.

UNIÃO AFRICANA (UA). Agenda de União africana para 2063, África que queremos. Adias Abebab, abril de 2015. http://www.au.int/en/Agenda2063/popular_version. Acessado em 10 abril de 2015 .

UNILAB. Diretrizes Gerais da Universidade da Integração Internacional da Lusofonia Afro-Brasileira, julho de 2010. Disponível em: http://pdi.unilab.edu.br/wpcontent/uploads/2013/08/Diretrizes Gerais UNILAB.pdf. Acessado em 10 de maio de 2015.

VAZ, Farã; MALOMALO, Bas'llele. Brasil-Moçambique: O lado oculto da Cooperação SulSul Triangular. III Semana Universitária, Unilab, Campus da Liberdade, Redenção, 19 a 22 de outubro de 2016 [Anais]. Disponível em: http://semanauniversitaria.unilab. edu.br/anais2016/. Acesso em: 29 ago. 2014.

VISENTINI, Paulo Fagundes. A África moderna: um continente em mudança. Porto Alegre: Leitura XXI, 2010.

WLADIMIR, Valler Filho. O Brasil e a crise haitiana: a cooperação técnica como instrumento de solidariedade e de ação diplomática. Brasília: FUNAG, 2007.

\section{Dados dos autores}

Bas'llele Malomalo

Doutor em Sociologia, docente no curso de Relações Internacionais e no Mestrado Interdisciplinar em Humanidades/ Universidade da Integração Internacional da Lusofonia Afro-brasileira e Líder do Grupo de Pesquisa África-Brasil: Produção do conhecimento, sociedade civil, desenvolvimento e cidadania global. E-mail: $\underline{\text { basilele@unilab.edu.br }}$

Julie Lourau

Doutora em Antropologia Social e Etnologia (EHESS), professora no Programa de Políticas Sociais e Cidadania da Universidade Católica do Salvador e Líder do Grupo de Pesquisa Antropologia Fronteiras Espaços e Cidadania (GP AFEC). E-mail: juliesarahba@gmail.com

Osmaria Rosa Souza

Mestra em Políticas Sociais e Cidadania pela Universidade Católica do Salvador, assistente Social e pesquisadora do Grupo de Pesquisa Antropologia Fronteiras Espaços e Cidadania (GP AFEC). E-mail: mari.pamais@gmail.com 